\title{
Magnitude-Frequency Distribution of Hummocks on Rockslide-Debris Avalanche Deposits and Its Geomorphological Significance
}

\author{
Hidetsugu Yoshida \\ Received: 24 November 2015; Accepted: 11 January 2016; Published: 19 January 2016 \\ Academic Editors: Yongwei Sheng and Jesus Martinez-Frias \\ Department of Geography, School of Arts and Letters, Meiji University, 1-1 Kanda-Surugadai, Chiyoda, \\ Tokyo 101-8301, Japan; yoshidah@meiji.ac.jp; Tel.: +81-3-3296-2240; Fax: +81-3-3296-2350
}

\begin{abstract}
A magnitude-frequency analysis of rockslide-debris avalanche deposits was performed. Hummocks are conical mounds formed in debris avalanche deposits from the catastrophic sector collapse of a mountain (often volcanic) that represent relatively cohesive fragments of the mountain edifice. Examination of 17 debris avalanche deposits in Japan and the Philippines showed that, in general, the larger the magnitude of the hummocks, the smaller their frequency. Hummocks followed an exponential distribution: $\log _{10} N(x)=\mathrm{a}-\mathrm{b} x$, where $N(x)$ is the cumulative number of hummocks with magnitude $\geqslant x$ and a and $\mathrm{b}$ are constants; $x$ is equal to $\log _{10} A$, where $A$ is the area of a hummock. The constants $\mathrm{a}$ and $\mathrm{b}$ were positively correlated. The value of $\mathrm{b}$, which differs among avalanches and in this analysis ranged between 1 and 3, may be controlled by the mobility of the debris avalanche. Avalanches with higher mobility (relatively longer runout) have higher $b$ and potentially produce more numerous fragments forming hummocks (i.e., higher a). From the above correlation, the magnitude-frequency relationship can be used to roughly estimate the original height of the collapsed volcanic body, if the runout distance of the rockslide-debris avalanche can be estimated with sufficient accuracy.
\end{abstract}

Keywords: magnitude-frequency relationship; rockslide-debris avalanche; hummock; exponential distribution; equivalent coefficient of friction; Japan

\section{Introduction}

Many studies have investigated the magnitude-frequency relationship of earth surface processes and landforms [1,2]. The best-known example may be the Gutenberg-Richter equation in seismology. In geomorphology, the frequency distribution of landslides is often analyzed, in part because landslides have significant impacts on human society but also to elucidate the relationship between landsliding potential and geologic [3] or climatic conditions and changes [4]. Landslides and other mass movements such as rocky mudflows, landcreeps, and steep-slope collapses show a similar distribution [5], which can be simply expressed by the following exponential equation:

$$
\log _{10} N(x)=\mathrm{a}-\mathrm{b} x
$$

where $N(x)$ is the cumulative number of landforms with magnitude $\geqslant x$ and a and $\mathrm{b}$ are constants; $x$ is equal to $\log _{10} A$, where $A$ is the landform area (e.g., landslide area).

In this study, the magnitude-frequency distribution of hummocks on the deposits of rockslide-debris avalanches was investigated. Hummocks, also occasionally called molards, are conical mound-like landforms that protrude from the surface of debris avalanche deposits associated with the catastrophic sector collapse of a volcanic edifice or other mountain [6-9]. The core of a 
hummock is usually a large (or mega) block, although, as observed at Mount St. Helens in 1980, it is possible for some hummocks to be composed entirely of fine materials [7,10]. Failures of volcanic masses consisting of alternating lava and tephra deposits are reported to produce hummocks when these brittle domains separate from each other during the collapse [11,12]. Such hummocks generally decrease in size downstream $[6,10,13]$, and this phenomenon has been quantitatively investigated in Japan [14]. Simple models that describe the progressive breaking up of volcanic masses or rockslide-debris avalanche blocks (hummocks) during avalanche spreading [15-17] have been partly proposed to explain this decrease. In these models, the volcanic edifice is initially broken into a few mega-blocks, and these mega-blocks subsequently break up along pre-existing weak surfaces before their emplacement as hummocks. One result of this process is that the amount of debris avalanche matrix (fine-grained sediments) gradually increases in the deposits downstream. The magnitude-frequency distribution of hummocks may thus provide new geomorphological insight into the processes of rockslide-debris avalanches.

\section{Data and Methods}

The magnitude-frequency distributions of hummocks in 17 hummocky terrains were investigated: 16 terrains in Japan and one in the Philippines (Figure 1, Table 1). The source volcano edifices were composed mainly of andesitic lava and pyroclastic deposits. Although Mt. Fuji, the highest volcano in Japan, is composed of basaltic materials, its steep slope makes it prone to catastrophic collapse.

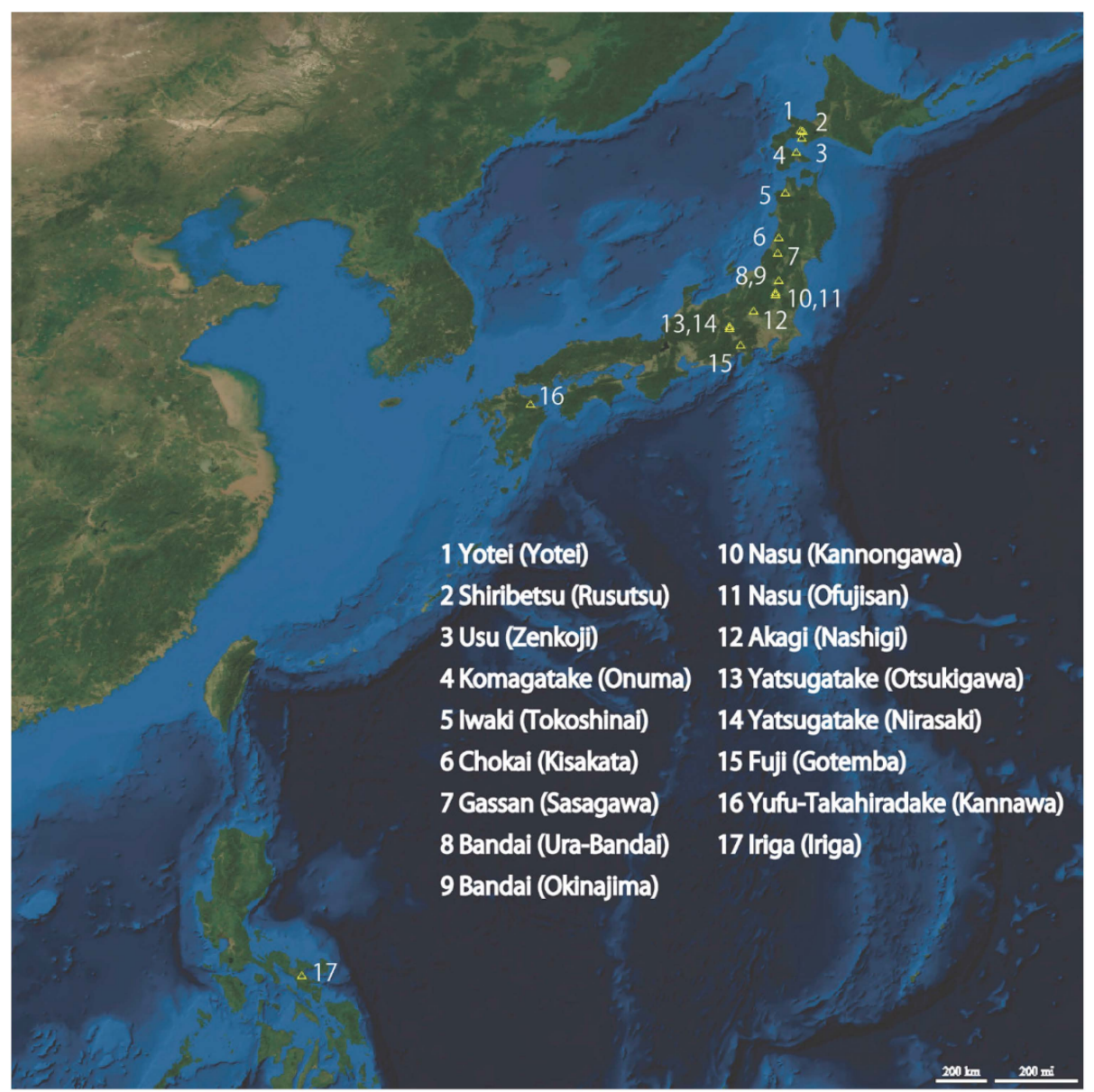

Figure 1. Locations of the studied volcanoes and rockslide-debris avalanches (names in parentheses). The base map was produced by using a Global Geodata dataset with GIS software (TNTmips) from MicroImages, Inc. (Lincoln, NE, USA). 
Table 1. The studied rockslide-debris avalanches. The asterisk denotes values based on the present summit. The double-asterisk denotes a value re-calculated from Yoshida et al. [14]. Part of data for the Nirasaki debris avalanche from Yatsugatake volcano are off record for avoiding confusion, owing to drastic topographic changes around the source area (burial by new eruptive products and erosion) and the depositional area (buried by wide and thick Kofu basin deposits), which leads to estimates of both $H$ and $L$ with comparatively larger errors.

\begin{tabular}{|c|c|c|c|c|c|c|c|c|}
\hline ID & Volcano & Debris Avalanche & Region & Number of Hummocks & Data Source & $\begin{array}{c}\text { Relative Height } \\
(H ; \mathbf{k m})\end{array}$ & $\begin{array}{c}\text { Runout Distance } \\
\qquad(L ; \mathbf{k m})\end{array}$ & $H / L$ \\
\hline 1 & Yotei & Yotei & Japan & 297 & Aerial photos & 1.55 & 12.0 & 0.129 \\
\hline 2 & Shiribetsu & Rusutsu & Japan & 172 & Aerial photos & 1.00 & 7.5 & 0.133 \\
\hline 3 & Usu & Zenkoji & Japan & 262 & Aerial photos & 1.05 & 7.0 & $0.150^{* *}$ \\
\hline 4 & Komagatake & Onuma (Kurumizaka) & Japan & 329 & Land Condition Map (GSI) & 1.00 & 11.0 & 0.091 \\
\hline 5 & Iwaki & Tokoshinai & Japan & 200 & Aerial photos & $1.60^{*}$ & 15.0 & 0.107 \\
\hline 6 & Chokai & Kisakata & Japan & 1185 & Aerial photos & 2.40 & 24.0 & 0.100 \\
\hline 7 & Gassan & Sasagawa & Japan & 265 & Aerial photos & 1.95 & 22.5 & 0.087 \\
\hline 8 & Bandai & Ura-Bandai & Japan & 1235 & Land Condition Map (GSI) & 1.20 & 11.0 & 0.109 \\
\hline 9 & Bandai & Okinajima & Japan & 900 & Land Condition Map (GSI) & 1.80 & 16.0 & 0.113 \\
\hline 10 & Nasu & Kannongawa & Japan & 230 & Aerial photos & 1.00 & 10.5 & 0.095 \\
\hline 11 & Nasu & Ofujisan & Japan & 643 & Aerial photos & 1.60 & 19.0 & 0.084 \\
\hline 12 & Akagi & Nashigi & Japan & 60 & Aerial photos & $2.40^{*}$ & 23.5 & 0.102 \\
\hline 13 & Yatsugatake & Otsukigawa & Japan & 26 & Aerial photos & 1.40 & 11.0 & 0.127 \\
\hline 14 & Yatsugatake & Nirasaki & Japan & 45 & Aerial photos & - & - & - \\
\hline 15 & Fuji & Gotemba & Japan & 566 & Land Condition Map (GSI) & 2.70 & 24.0 & 0.113 \\
\hline 16 & Yufu-Takahiradake & Kannawa & Japan & 23 & Aerial photos & 0.80 & 5.2 & 0.154 \\
\hline 17 & Iriga & Iriga & Philippines & 303 & Aerial photos & 1.25 & 11.0 & 0.114 \\
\hline
\end{tabular}


Hummocks were identified by using a stereoscope to manually interpret aerial photographs, with occasional reference to a geomorphic map, such as the Land Condition Map of Volcanoes published by the Geographical Survey Institute (GSI) of Japan (Figure 2). The hummock size-distance relationship and morphological processes of some of these terrains have been investigated previously [14,18-22]. For two avalanche deposits on Bandai volcano, a few small hummocks were previously excluded from the regression analysis of the size-distance relationship, as likely derived from secondary and much smaller collapses following (possibly just after) the huge main collapse event [18]. Such small hummocks have been included in this investigation, but because they are few in number, they are unlikely to affect the main results.

In brief, the data collection procedure was as follows. First, the outline of each hummock was traced on an aerial photograph. Aerial photographs taken in Japan by GSI in the 1960s and 1970s (scale, about 1:20,000 or 1:25,000) and, for Iriga, by the National Mapping and Resource Information Authority of the Philippines in 1988 (scale about 1:36,000) were used. Next, the photographs and tracings were scanned at a resolution of $400 \mathrm{dpi}$. Then, GIS software (TNTmips, MicroImages, Inc. (Lincoln, NE, USA) was used to convert the scanned images into digital orthophotographs, which were rectified by using digital elevation models (DEMs) published by GSI (for Japanese volcanoes) or an ASTER GDEM from the Japanese Earth Remote Sensing Data Analysis Center (for Iriga). For some Japanese volcanoes, Land Condition Maps were scanned and converted to digital images so that the hummocks could be accurately traced. Finally, the hummock outlines were digitized into polygons in the GIS database, and the area of each polygon was measured. The magnitude of each hummock, defined as the logarithm of its area in plan view (uncorrected for ground slope), is a fundamental morphometric parameter of hummocks.
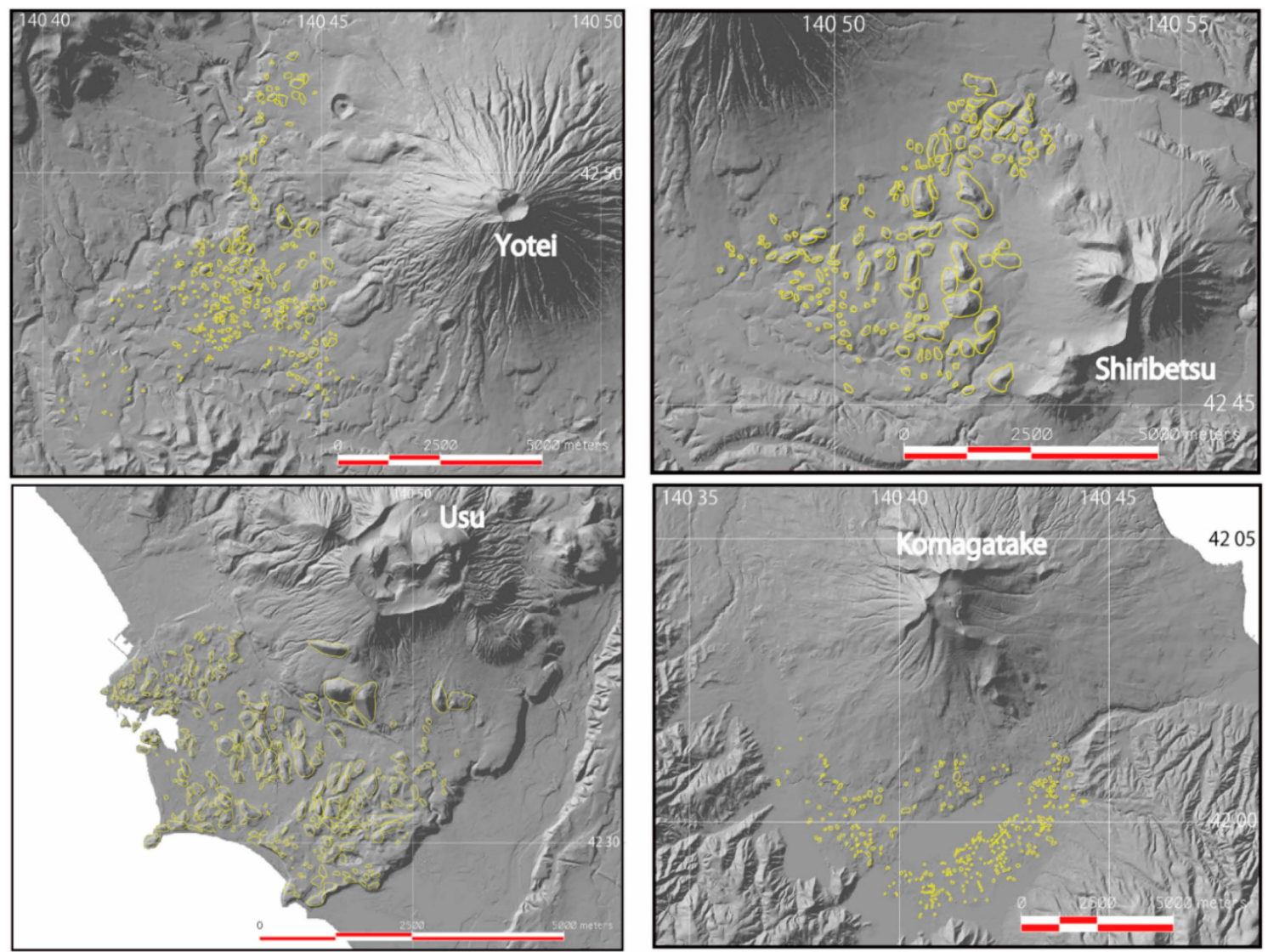

Figure 2. Cont. 

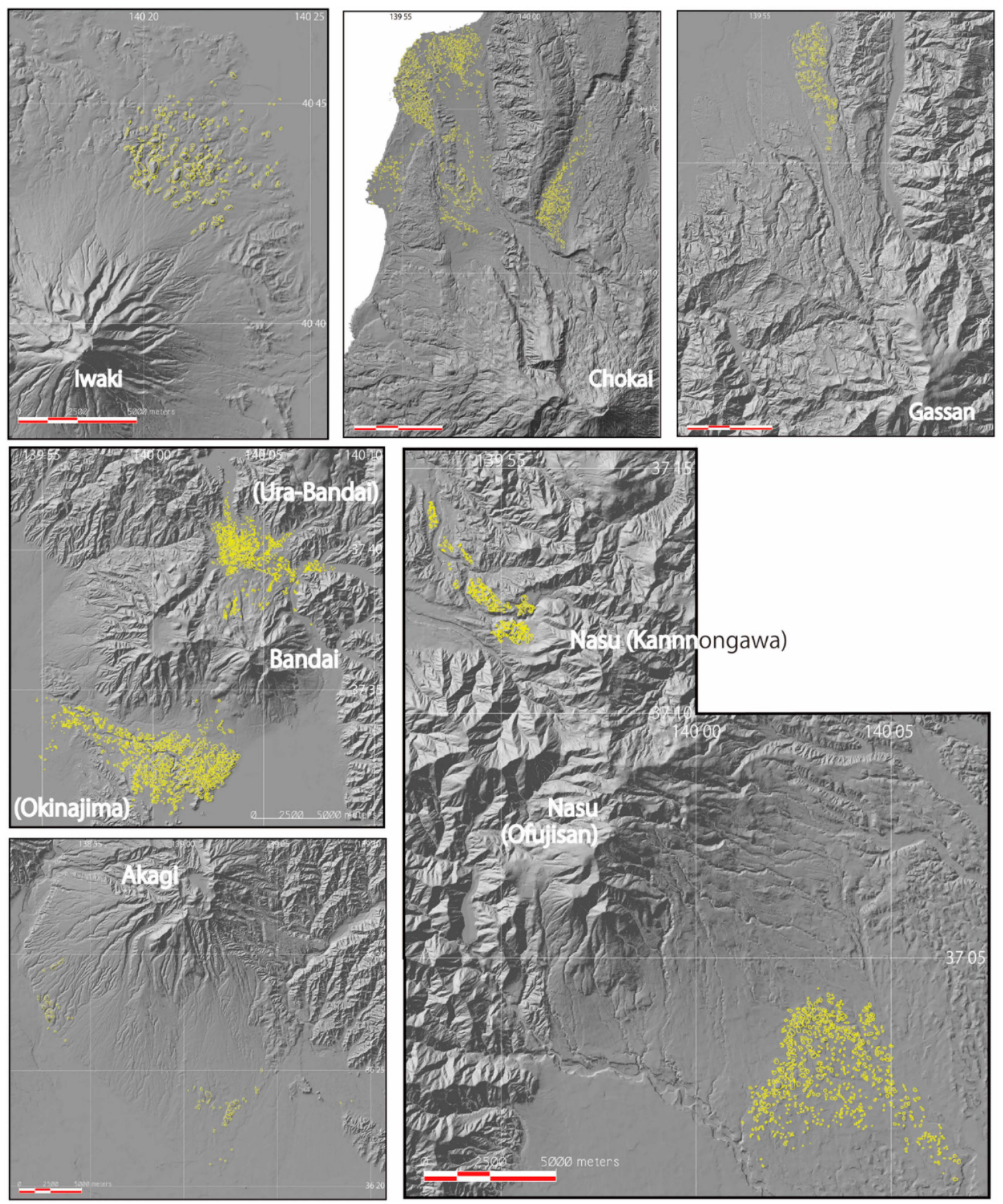

Figure 2. Cont. 

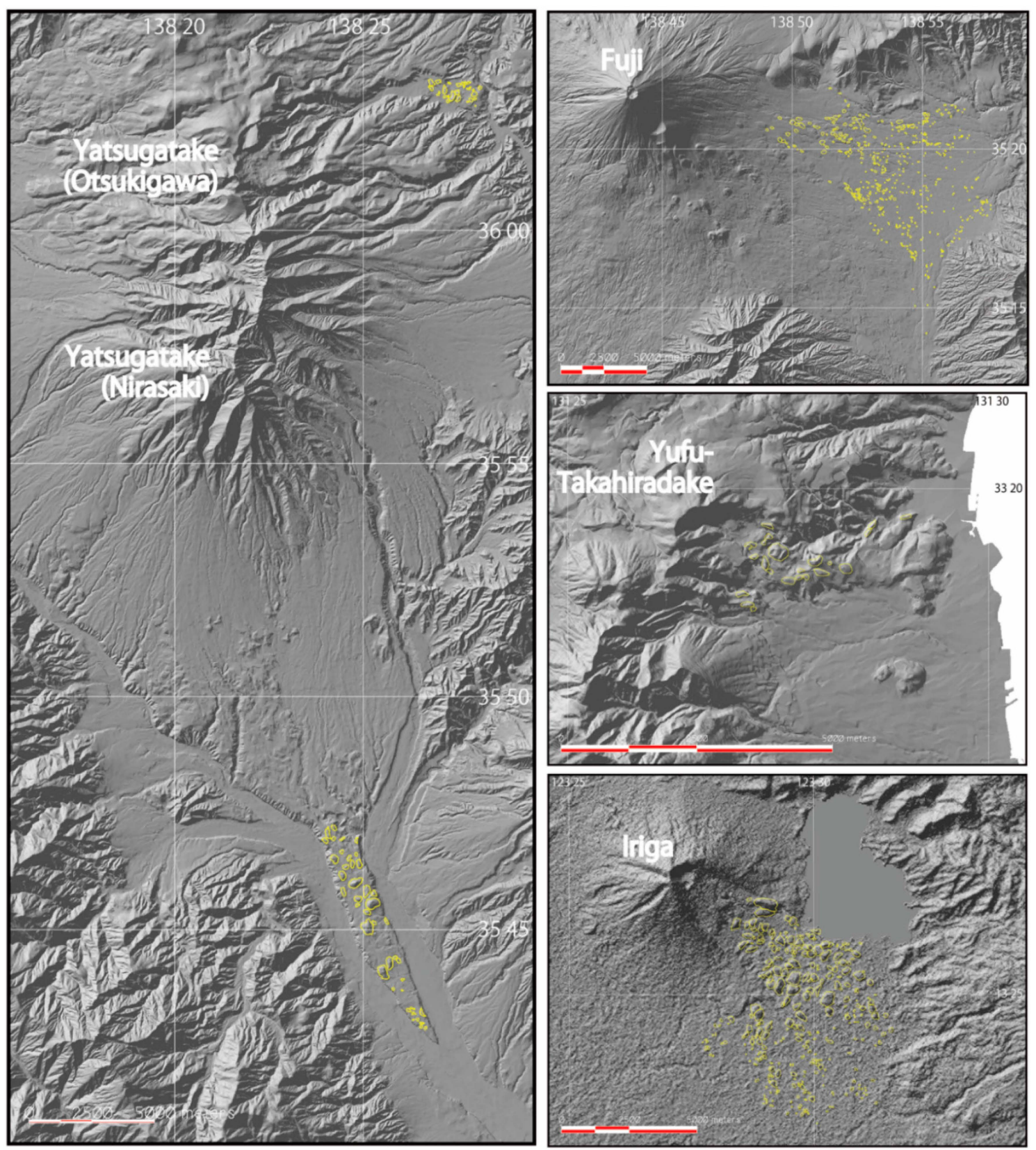

Figure 2. Spatial distributions of hummocks in the examined debris avalanches. The base maps for the Japanese examples are based on 10-m-mesh digital elevation data from the Geographical Survey Institute, Japan, and that for Iriga is based on ASTER GDEM data from the Japanese Earth Remote Sensing Data Analysis Center.

As a rockslide-debris avalanche mobility index, the equivalent coefficient of friction $(H / L)$ was used [23], where $H(\mathrm{~km})$ is relative height or fall height and $L(\mathrm{~km})$ is the travel distance. Here, $H$ is defined as the altitudinal difference between the pre-collapse summit of the volcano and the probable terminal position of the avalanche, which can often be identified with a relatively small error. $L$ is defined as the horizontal length of the avalanche from the pre-collapse summit to the probable terminus. If topographical changes drastically obscured the collapse scar, so that the original summit could not be reconstructed, $L$ and $H$ were estimated under the simple assumption that the highest point before collapse was the same as the present summit. Such cases are those in Iwaki and Akagi volcanoes. It is possible that larger errors than the other cases may be left. However, the above two cases, along 
with the others, also follow a clearly observed trend with strong correlation of $H / L$ values of the debris avalanches with the rate of decrease of hummock size [14]. Thus, the expected errors might be smaller as far as the values of $H / L$ are concerned. In general, $H / L$ values of terrestrial debris avalanches range from 0.05 (more mobile) to 0.18 [24] or 0.20 [13] (less mobile). Those of the studied debris avalanches ranged from 0.084 to 0.150 (Table 1).

\section{Results and Discussion}

\subsection{Data Analysis}

The procedure used to determine the magnitude-frequency distribution of hummocks is illustrated by using the Yotei debris avalanche from Yotei volcano as an example.

The hummocks in the Yotei debris avalanche are distributed on the western piedmont of Yotei volcano (Figure 2). To obtain the magnitude-frequency distribution, the hummock magnitudes were grouped into bins of 0.2 (Figure 3).

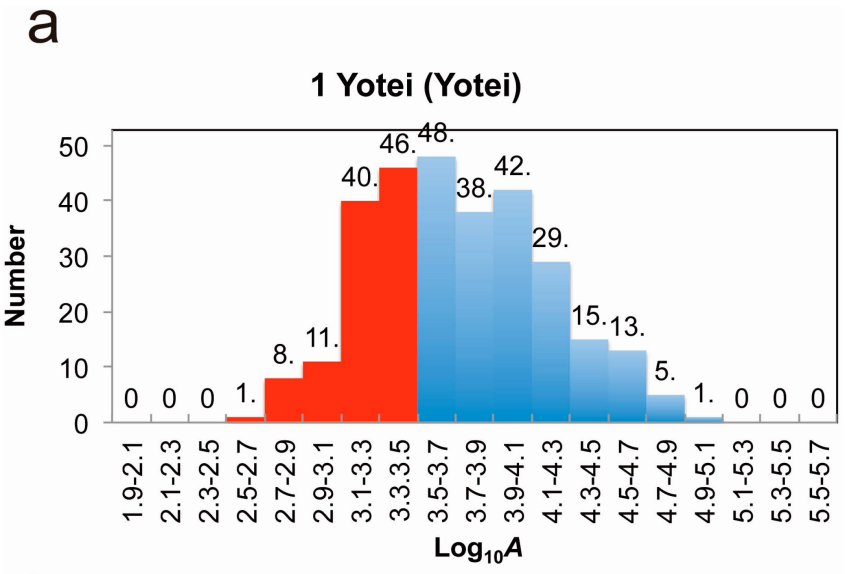

b

$\log _{10} A$

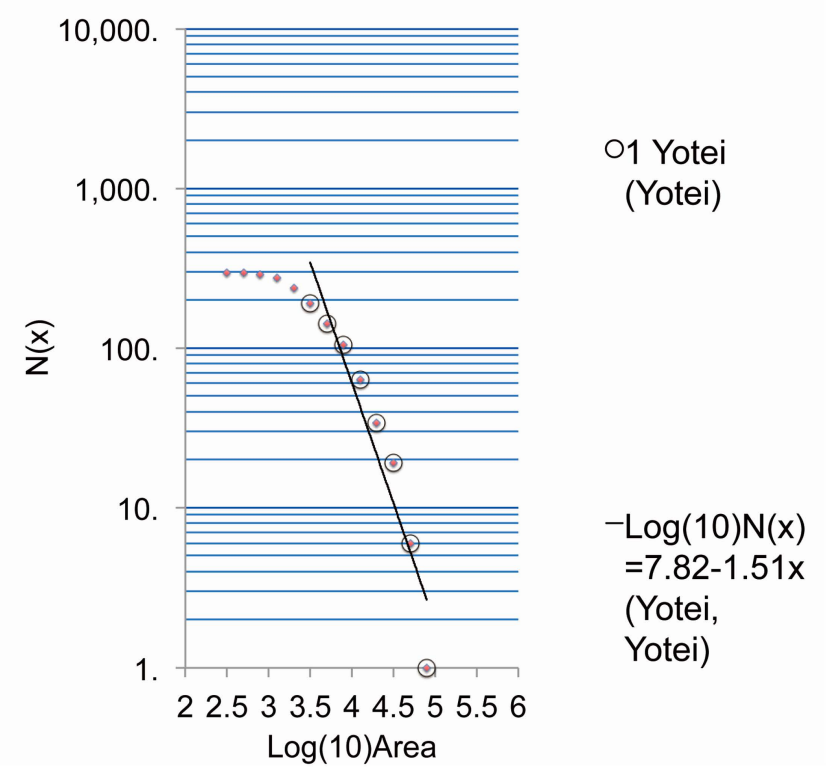

Figure 3. The magnitude-frequency distribution of hummocks in the Yotei debris avalanche (ID 1). (a) Magnitude-frequency histogram $\left(\log _{10} A\right.$ values, 0.2 per bin). The red bins were excluded from the regression analysis; (b) Regression analysis result obtained by fitting Equation (1) to the circled data points. 
The hummock magnitude-frequency distribution of the Yotei debris avalanche (Figure 3a) was unimodal. In this study, because the aim was to consider single debris transport events, hummocks with smaller magnitudes (red bars in Figure 3a) are considered to be unreliable because a debris avalanche block that travels a long distance from the source region may be almost completely broken up to such an extent that few hummocks are identifiable. An additional reason that the smaller hummocks can be ignored when characterizing the distribution is technical; because the hummocks are identified on aerial photographs with scales of 1:20,000-1:25,000, smaller hummocks are likely to be undercounted.

This phenomenon, which is often seen in logarithmic cumulative frequency graphs of landforms, is called "rollover" [25-27]. Although rollover in a landslide magnitude-frequency curve may present problems in understanding landslides [28], in this research, it is possible to exclude a few small-magnitude bins from the regression analysis because each hummocky terrain is regarded as having been produced all at once by a single rockslide-debris avalanche event. During an individual event, mega-blocks may become disaggregated, reducing their potential to form hummocks. As a result, smaller blocks may become buried under the increased matrix that forms during transport, and these small buried blocks would not be counted as hummocks during sampling.

In the case of the Yotei debris avalanche, for example, the five smallest bins (Figure 3a) were excluded, based on the arbitrary rule that bins with a cumulative ratio $<0.5$ in ascending order should be discarded, which has been applied to all cases in the next section (Figure 4). The results and conclusions of the current research would be essentially the same if a cumulative ratio of 0.2 were used as the threshold instead.

Because magnitudes greater than 3.5 on the cumulative frequency graph of the Yotei debris avalanche formed an almost straight line, a regression analysis performed using Equation (1) showed a high correlation $(R=-0.952)$. The fitted values of a and b were 7.82 and 1.51 , respectively (Figure $3 \mathrm{~b}$ ).

Here, further rigorous treatment should have been requested in that it makes sense to work with only one threshold of hummock size for all cases, as more realistic technical treatment based on hummock identification using aerial photographs or others. However, a wide range in hummock size among the cases makes it impossible to provide a single threshold size (Figure 4). For such an occasion, in order to keep an objective to compare among the cases, the author has focused on the commonly observed event that the "relatively larger" hummocks of each case decrease in number, from unimodal patterns of magnitude-frequency.

\subsection{General Characteristics of the Magnitude-Frequency Distribution of Hummocks}

The magnitude-frequency histograms of all of the studied rockslide-debris avalanches, with the excluded bins shown in red, are shown in Figure 4.

Equation (1) was fitted to the hummock magnitude-frequency distributions (excluding some small-magnitude bins) of all of the studied avalanches, and in each case the correlation coefficient was high, indicating that the equation described the data well (Figure 5, Table 2). The value of constant a range between 5 and 11, and the value of $b$ ranged between 1 and 3 (Table 2). Moreover, the two constants are strongly and positively correlated with each other $(R=0.970$; Figure 6$)$ as follows:

$$
a=4.0293 b+1.7469
$$

Therefore, by substituting Equation (2) into Equation (1), the magnitude-frequency distribution of hummocks can be expressed in terms of the constant $b$ as

$$
\log _{10} N(x)=\mathrm{a}-\mathrm{b} x=(4.0293-x) \mathrm{b}+1.7469
$$



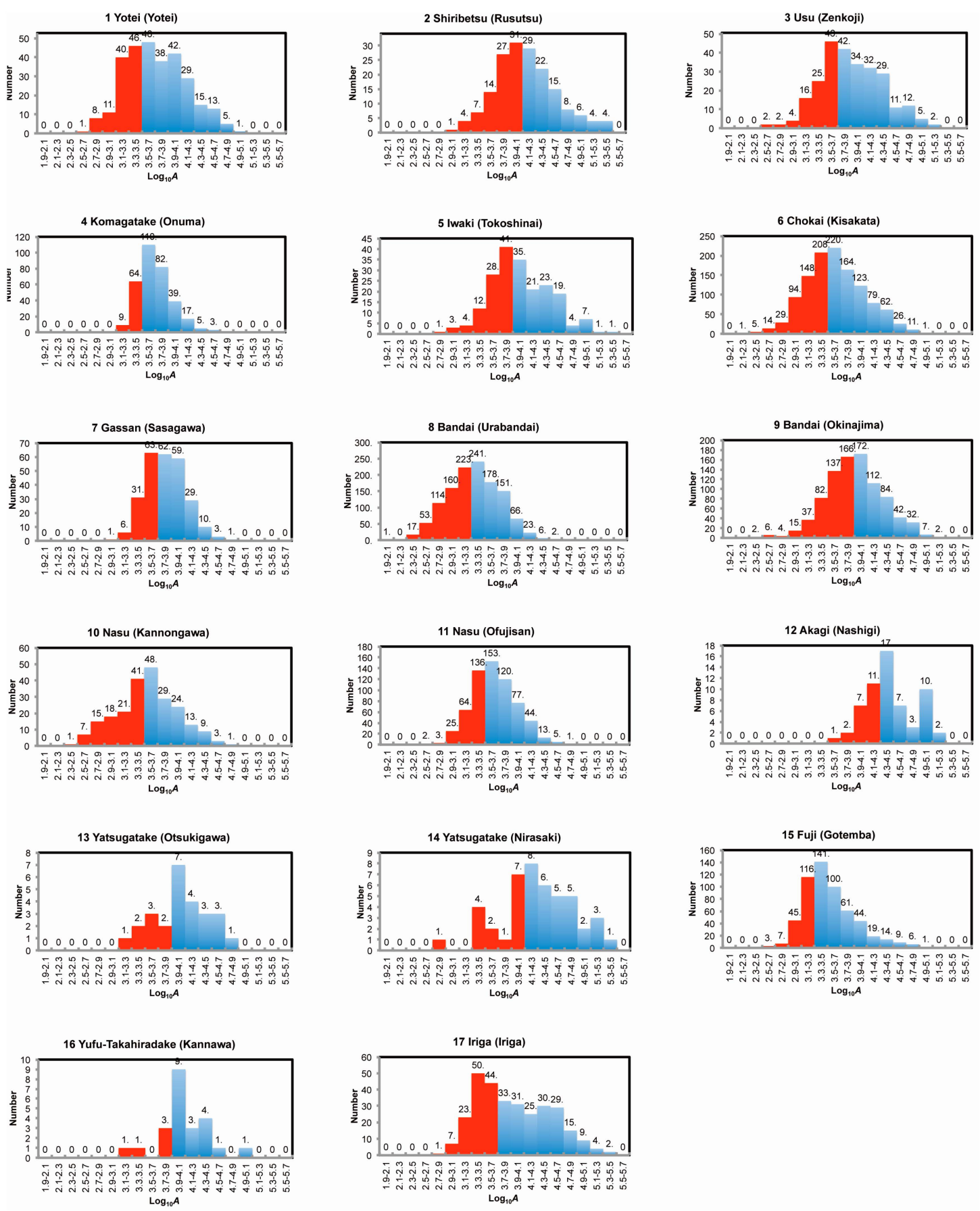

Figure 4. Hummock magnitude-frequency histograms of all studied avalanches. The red bins were excluded from the regression analysis. 

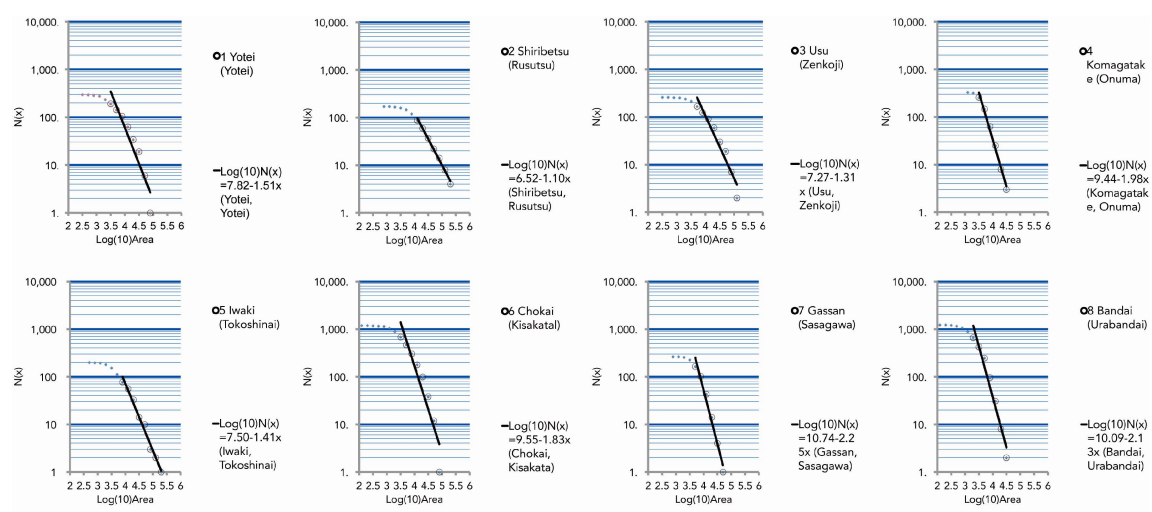

$\underset{\text { (U) Bandaia }}{\text { (Urabanda) }}$
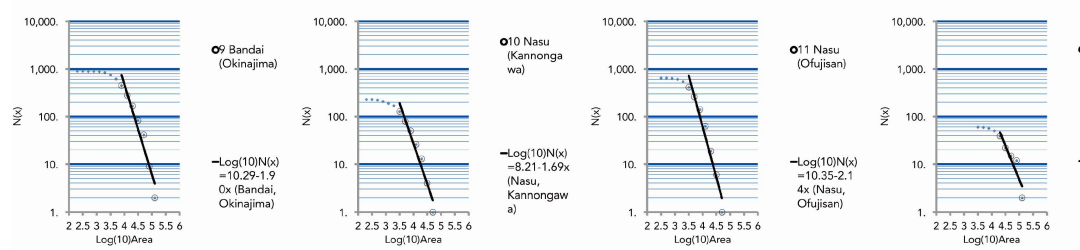

O12 2kagi
(Nassigi)
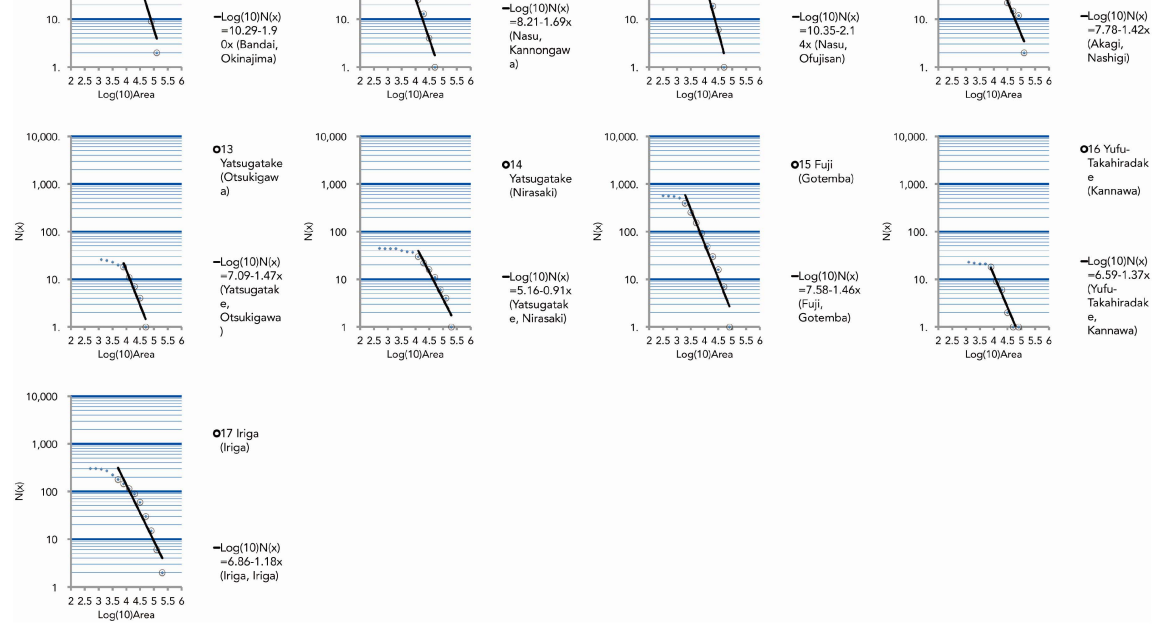

Figure 5. Magnitude-cumulative frequency distributions of all examined rockslide-debris avalanches showing the regression lines fitted to the encircled data points.

Table 2. Fitted values of constants a and b and the correlation coefficient of the regression analysis $(R)$ for the studied debris avalanches.

\begin{tabular}{cccccc}
\hline ID & Volcano & Debris avalanche & $\mathbf{a}$ & $\mathbf{b}$ & $\boldsymbol{R}$ \\
\hline 1 & Yotei & Yotei & 7.82 & 1.51 & -0.952 \\
2 & Shiribetsu & Rusutsu & 6.52 & 1.10 & -0.997 \\
3 & Usu & Zenkoji & 7.27 & 1.31 & -0.969 \\
4 & Komagatake & Onuma & 9.44 & 1.98 & -0.995 \\
5 & Iwaki & Tokoshinai & 7.50 & 1.41 & -0.993 \\
6 & Chokai & Kisakata & 9.55 & 1.83 & -0.944 \\
7 & Gassan & Sasagawa & 10.74 & 2.25 & -0.988 \\
8 & Bandai & Ura-Bandai & 10.09 & 2.13 & -0.982 \\
9 & Bandai & Okinajima & 10.29 & 1.90 & -0.971 \\
10 & Nasu & Kannongawa & 8.21 & 1.69 & -0.976 \\
11 & Nasu & Ofujisan & 10.35 & 2.14 & -0.978 \\
12 & Akagi & Nashigi & 7.78 & 1.42 & -0.925 \\
13 & Yatsugatake & Otsukigawa & 7.09 & 1.47 & -0.965 \\
14 & Yatsugatake & Nirasaki & 5.16 & 0.91 & -0.947 \\
15 & Fuji & Gotemba & 7.58 & 1.46 & -0.971 \\
16 & Yufu-Takahiradake & Kannawa & 6.59 & 1.37 & -0.978 \\
17 & Iriga & Iriga & 6.86 & 1.18 & -0.961 \\
\hline
\end{tabular}




\subsection{Rockslide-Debris Avalanche Processes Inferred from the Magnitude-Frequency Distributions of Hummocks}

Because hummocks generally decrease in size downstream, the constant $b$, which is the slope of the fitted regression line (Equation (1)), may reflect kinematic differences among events caused by temporal and spatial differences in the break-up of the sliding mass along the avalanche path. When a volcanic mass collapses and during its movement as a debris avalanche, it breaks up into numerous blocks. Each hummock is thus basically composed of a cohesive piece of the rock mass. Simple models have been proposed to describe the progressive breaking up of volcanic masses and rockslide-debris avalanche blocks during avalanche spreading to form hummocks $[15,16,29]$. Thus, the value of $b$, which represents the rate at which the number of the debris avalanche blocks forming hummock cores increases as hummock magnitude decreases, directly reflects debris avalanche processes and thus has geomorphological significance.

The value of $b$ may be controlled by the mobility of the rockslide-debris avalanche, because when a debris avalanche is more mobile, the collapsed and sliding masses composing the avalanche are more likely to become shattered and broken up as they move, resulting in the emplacement of more numerous hummocks. Although it is possible that the trigger of the sector collapse (volcanic or seismic) or the material properties of the edifice also affect the formation processes of hummocks, little information is available for assessing these possibilities. Therefore, in this research, the equivalent coefficient of friction $(H / L)$ was used as a non-dimensional mobility index to characterize rockslide-debris avalanche events (Table 1). Some of the values in the table are based on published sources [14,18-22], and others have been re-calculated or newly estimated. In general, $H / L$ values of volcanic rockslide-debris avalanches range from 0.05 (more mobile) to 0.18 (less mobile) [24], and all of the avalanches included in this study have $H / L$ values in this range.

A strong correlation was found between $H / L$ and $\mathrm{b}(R=-0.693)$, which supports the hypothesis that the value of $b$ is controlled by the avalanche mobility (Figure 7):

$$
b=f(H / L)=-11.899(H / L)+2.98
$$

Equation (4) indicates that when $H / L$ is greater (i.e., the debris avalanche is less mobile) $b$ is lower. Furthermore, because $\mathrm{a}$ and $\mathrm{b}$ are positively correlated, a debris avalanche with higher mobility (i.e., higher $b$ ) can potentially produce a greater number of fragments from the original volcanic rock mass (i.e., higher a).

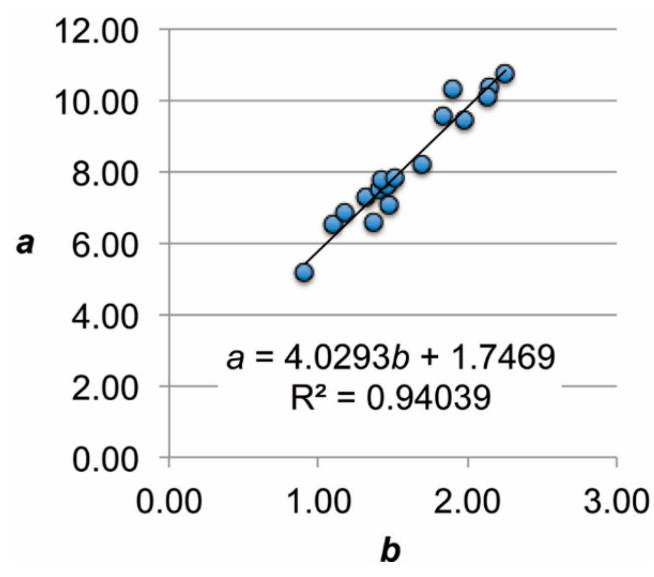

Figure 6. Relationship between $a$ and $b(N=17)$ and the fitted linear regression line. Constants $a$ and $b$ are retrieved by regression analysis performed using Equation (1). 


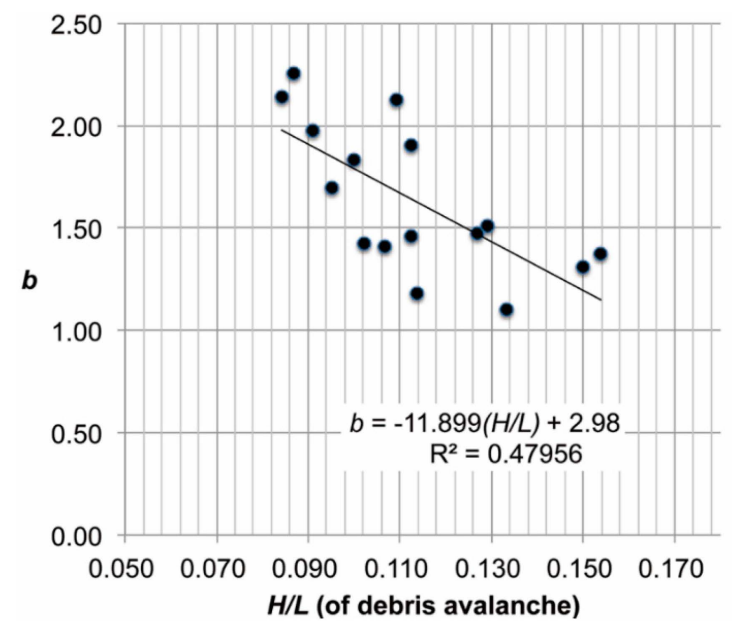

Figure 7. Relationship between $H / L$ and constant $b(N=16)$. Data for the Nirasaki debris avalanche from Yatsugatake volcano have been excluded from the regression analysis; owing to drastic topographic changes around the source area (burial by new eruptive products and erosion) and the depositional area (buried by wide and thick Kofu basin deposits), the hummock sampling was excessively incomplete and estimates of both $H$ and $L$ might have comparatively large errors. The straight line indicates the regression line.

\subsection{Geomorphological Significance}

The geomorphological significance of the hummock magnitude-frequency distribution was inferred from the above results as follows. By substituting Equation (4) into Equation (3), the following relationship was obtained:

$$
\log _{10} N(x)=(4.0293-x) f(H / L)+1.7469
$$

Equation (5) can be used to estimate the number of hummocks if the equivalent coefficient of friction of the rockslide-debris avalanche (i.e., $H / L$ ) is known or can be estimated. Conversely, the number of hummocks can be used to estimate the mobility of the rockslide-debris avalanche that produced them. Then, from the mobility and the travel distance $(L)$ of the debris, estimated as described in section 2, the fall height $(H)$ of the sliding mass can be estimated. Therefore, Equation (5) can be used to reconstruct the original altitude of the collapsed volcanic body, even if drastic topographical changes have occurred since the collapse event, and this information can be used in the reconstruction of the volcano's history.

Acknowledgments: My thanks to anonymous reviewers for their fruitful comments on improving the paper. The study was financially supported by a grant for "Research by Young Researchers" from Meiji University in 2014. The author thanks Hitoshi Saito, Kanto Gakuin University in Japan, and Oliver Korup, Potsdam University in Germany, for their encouragement concerning the study.

Conflicts of Interest: The author declares no conflict of interest.

\section{References}

1. Wolman, M.G.; Miller, J.P. Magnitude and frequency of forces in geomorphic processes. J. Geol. 1960, 68, 54-74. [CrossRef]

2. Hirano, M.; Ohmori, H. Magnitude-frequency distribution for rapid mass movements and its geomorphological implication. Trans. Jpn. Geomorphol. Union 1989, 10, 95-111. (In Japanese)

3. Sugai, T.; Ohmori, H.; Hirano, M. Rock control on magnitude-frequency distribution of landslides. Trans. Jpn. Geomorphol. Union 1994, 15, 233-251. 
4. Korup, O.; Görüm, T.; Hayakawa, Y. Without power? Landslide inventories in the face of climatic change. Earth Surf. Process. Landf. 2012, 37, 92-99. [CrossRef]

5. Ohmori, H.; Hirano, M. Magnitude, frequency and geomorphological significance of rocky mud flows, landcreep and the collapse of steep slopes. Zeitschrift fur Geomorphology 1988, 67, 55-65.

6. Ui, T.; Takarada, S.; Yoshimoto, M. Debris avalanches. In The Encyclopedia of Volcanoes, 2nd ed.; Sigurdsson, H., Houghton, B., McNutt, S., Rymer, H., Stix, J., Eds.; Academic Press: San Diego, CA, USA, 2000; pp. 617-626.

7. Van Wyk de Vries, B.; Davies, T. Landslides, debris avalanches and volcanic gravitational deformation. In The Encyclopedia of Volcanoes, 2nd ed.; Sigurdsson, H., Houghton, B., McNutt, S., Rymer, H., Stix, J., Eds.; Academic Press: San Diego, CA, USA, 2015; pp. 665-685.

8. Calhoun, N.; Poschinger, A.V.; Clague, J.J.; Giardino, M.; Masera, D.; Perotti, L. New Pieces to the Flims-Tamins Rockslide Puzzle. In Engineering Geology for Society and Territory-Volume 2; Lollino, G., Giordan, D., Crosta, G., Corominas, J., Azzam, R., Wasowski, J., Sciarra, N., Eds.; Springer International Publishing: Cham, Switzerland, 2015; pp. 899-903.

9. Geertsema, M.; Hungr, O.; Schwab, J.W.; Evans, S.G. A large rockslide-debris avalanche in cohesive soil at Pink Mountain, northeastern British Columbia, Canada. Eng. Geol. 2006, 83, 64-75. [CrossRef]

10. Glicken, H. Rockslide-Debris Avalanche of May 18, 1980, Mount St. Helens volcano, Washington; USGS Open-File Report 96-677. USGS: Reston, VA, USA, 1996; pp. 1-90.

11. Shea, T.; van Wyk de Vries, B. Structural analysis and analogue modeling of the kinematics and dynamics of rockslide avalanches. Geosphere 2008, 4, 657-686. [CrossRef]

12. Andrade, S.; van Wyk de Vries, B. Structural analysis of the early stages of catastrophic stratovolcano flank-collapse using analogue models. Bull. Volcanol. 2010, 72, 771-789. [CrossRef]

13. Siebert, L. Large volcanic debris avalanches: Characteristics of source areas, deposits, and associated eruptions. J. Volcanol. Geotherm. Res. 1984, 22, 163-197. [CrossRef]

14. Yoshida, H.; Sugai, T.; Ohmori, H. Size-distance relationship for hummocks on volcanic rockslide-debris avalanche deposits in Japan. Geomorphology 2012, 136, 76-87. [CrossRef]

15. Clavero, J.E.; Sparks, R.S.J.; Huppert, H.E. Geological constraints on the emplacement mechanism of the Parinacota debris avalanche, northern Chile. Bull. Volcanol. 2002, 64, 40-54. [CrossRef]

16. Paguican, E.M.R.; van Wyk de Vries, B.; Lagmay, A.M.F. Hummocks: how they form and how they evolve in rockslide-debris avalanches. Landslides 2012, 11, 67-80. [CrossRef]

17. Cassie, J.W.; van Gassen, W.; Cruden, D.M. Laboratory analogue of the formation of molards, cones of rock-avalanche debris. Geology 1988, 16, 735-738. [CrossRef]

18. Yoshida, H. Evaluation of the 1888 sector-collapse volume of Bandai volcano, Japan, in terms of the size-distance distribution pattern of debris avalanche hummocks. Trans. Jpn. Geomorphol. Union 2012, 33, 45-60. (In Janpanese)

19. Yoshida, H. Longitudinal distribution pattern of hummocks of Kannongawa debris avalanche deposits, Nasu Volcanic Group, Japan, as an example of valley-filling debris avalanches due to the inland volcanic sector-collapse. Sundai Hist. Rev. 2012, 146, 19-36. (In Janpanese)

20. Yoshida, H. Reexamination of volume loss due to the catastrophic sector-collapse causing the Okinajima debris avalanche of Bandai volcano, Japan. Trans. Jpn. Geomorphol. Union 2013, 34, 1-19. (In Janpanese)

21. Yoshida, H. Restored image of volcanic sector collapse at "Old" Yotei volcano, southwestern Hokkaido of Japan, by the geomorphological interpretation of hummocks' distribution. J. Geogr. 2015, 124, 575-586. (In Janpanese) [CrossRef]

22. Yoshida, H. Decrease of size of hummocks with downstream distance in the rockslide-debris avalanche deposit at Iriga volcano, Philippines: similarities with Japanese avalanches. Landslides 2013, 10, 665-672. [CrossRef]

23. Hsü, K.J. Catastrophic debris streams (Sturzstroms) generated by rockfalls. Geol. Soc. Am. Bull. 1975, 86, 129-140. [CrossRef]

24. Siebert, L.; Glicken, H.; Ui, T. Volcanic hazards from Bezymianny- and Bandai-type eruptions. Bull. Volcanol. 1987, 49, 435-459. [CrossRef]

25. Hovius, N.; Stark, C.P.; Allen, P.A. Sediment flux from a mountain belt derived from landslide mapping. Geology 1997, 25, 231-234. [CrossRef]

26. Malamud, B.D.; Turcotte, D.L.; Guzzetti, F.; Reichenbach, P. Landslide inventories and their statistical properties. Earth Surf. Process. Landf. 2004, 29, 687-711. [CrossRef] 
27. Korup, O. Landslides in the Earth system. In Landslides: Types, Mechanisms and Modeling; Clague, J.J., Stead, D., Roberts, N., Korup, O., Hovius, N., Meunier, P., Waythomas, C.F., Davies, T., McSaveney, M., Hermanns, R.L., et al., Eds.; Cambridge University Press: Cambridge, UK, 2015; pp. 10-23.

28. Guthrie, R.H.; Deadman, P.J.; Cabrera, A.R.; Evans, S.G. Exploring the magnitude-frequency distribution: A cellular automata model for landslides. Landslides 2008, 5, 151-159. [CrossRef]

29. Dufresne, A.; Davies, T.R. Longitudinal ridges in mass movement deposits. Geomorphology 2009, 105, 171-181. [CrossRef]

(C) 2016 by the author; licensee MDPI, Basel, Switzerland. This article is an open access article distributed under the terms and conditions of the Creative Commons by Attribution (CC-BY) license (http://creativecommons.org/licenses/by/4.0/). 